\title{
Nutritional composition analysis of Ficus odorata (Blanco) Merr.: a road to its prebiotic potential
}

\author{
Librado A. Santiago ${ }^{1,2,3 *} \mathcal{E}$ Anna Beatriz Mayor ${ }^{3}$ \\ ${ }^{1}$ Research Center for the Natural and Applied Sciences \\ ${ }^{2}$ Departmentof Biochemistry-Faculty of Pharmacy \\ ${ }^{3}$ The Graduate School \\ University of Santo Tomas \\ España Boulevard, 1015 Manila, PHILIPPINES
}

\begin{abstract}
Ficus odorata (Blanco) Merr., is an indigenous ethnomedicinal plant widely cultivated in Luzon and commonly used by the Aetas of Bataan for treating several ailments. There are no known reports as to its nutritional composition hence, this study. Thus, the study aimed to unravel the nutritional contents of $F$. odorata and relate it to the possible application on various medications for certain diseases and as a candidate for being a prebiotic agent. Results show that the plant contains high carbohydrates (45.7\%) and dietary fibers (36.1\%) with sufficient amount of proteins (15.2\%) and less total fat (4.7\%) content. Lastly, micronutrient analysis revealed that the plant is rich in calcium (3.35\%) followed by potassium $(1.38 \%)$ and with trace amounts of sodium and zinc. Ficus odorata is a fiber-rich food ingredient that can provide a wide range of health benefits. Moreover, it can be used as a prebiotic agent that can ably support the growth of probiotics. Therefore, F. odorata leaf powder may be a potential functional food component as prebiotics for probiotics.
\end{abstract}

Keywords: Ficus odorata, endemic, nutrition, prebiotics, dietary fibers

\section{INTRODUCTION}

Ficus odorata (Blanco) Merr., commonly known as Pakiling or Is-is, is an indigenous ethnomedicinal plant of the mulberry family (Moraceae). It is widely cultivated in Tayabas, Zambales, Pamapanga, Laguna, and Bataan and extensively used by the Aetas of Bataan, Philippines for several ailments including diabetes, cancer, tumor, allergy, asthma, and diarrhea [1]. Though the plant is widespread for having many medicinal uses, scientific studies

*To whom correspondence should be addressed santiagolibrado@yahoo.com scarcely support these claims. Which is why, investigations were conducted in order to provide a more conclusive explanation as to how the plant provides major health benefits.

A previous study validated the plant's hypoglycemic activity on streptozotocininduced diabetes rat model wherein the dichloromethane (DCM) fraction of $F$. odorata, both $50 \mathrm{mg} / \mathrm{kg}$ and $200 \mathrm{mg} / \mathrm{kg}$ concentration per orem, produced a significant decrease in the mean fasting blood sugar levels of diabetic rats after a 14-day treatment and is safe at $2000 \mathrm{mg} /$ $\mathrm{kg}$ dose [2]. In another study, ethanolic crude 
leaf extract of $F$. odorata was established to have a pro-oxidant activity towards a group of physiologically important free radicals such as superoxide anion and hydroxyl free radicals and hydrogen peroxide [3]. A recent study substantiates its anticancer potential. The plant was shown to be cyotoxic and genotoxic on human hepatocellular carcinoma cell lines (HepG2) in vitro wherein F. odorata inhibited the growth in a concentration-dependent manner $\left(\mathrm{IC}_{50}=25 \mu \mathrm{g} / \mathrm{mL}\right.$ ) and likewise induced DNA damage even at $20 \mu \mathrm{g} / \mathrm{mL}$ concentration [4]. The chemical constituents of the F. odorata has been previously identified through $1 \mathrm{D}$ and 2D NMR spectroscopy and was shown to have $\beta$-sitosteryl-3 $\beta$-glucopyranoside-6-O-palmitate, squalene, lutein, $\alpha$-amyrin acetate, lupeol acetate, and $\beta$-carotene [5]. But no studies so far dealt on the nutritional composition of $F$. odorata that could probably provide insight and understanding on why its dietary nutrients can be relevant.

\section{Materials AND METHODS}

\section{Assessment of the nutritional content of F. odorata}

Plant collection and processing. Fresh leaves of $F$. odorata were collected from Barangay Igbac, Buhi, Camarines Sur in Bicol, Philippines and was authenticated by the Botany Division of the Philippine National Museum. The leaves were air-dried and were ground using WileyMill grinder and the powdered leaves were stored in a tightly sealed plastic container $[3,4]$.

Chemical analysis. The powdered leaves of $F$. odorata were sent to the Food Analytical Services Laboratory of the Department of Science and Technology-Food and Nutrition Research Institute (DOST-FNRI), Philippines to analyze and determine its nutritional value as summarized in Table 1.
Table 1. Chemical analysis performed to the powdered leaves of $F$. odorata for the assessment of its nutritional content

\begin{tabular}{l|c}
\hline \multicolumn{1}{c|}{ Analyte } & Method \\
\hline Total Fat & Acid Hydrolysis \\
\hline Ash & Gravimetric \\
\hline Moisture & Air/Oven Vacuum Oven \\
\hline Dietary Fiber & Enzymatic, AOAC \\
\hline Total Carbohydrates & $\begin{array}{c}\text { Computation from } \\
\text { proximate analyses }\end{array}$ \\
and Energy & Kjeldahl method \\
\hline Crude Protein & $\begin{array}{c}\text { Atomic Absorption } \\
\text { Spectroscopy (AAS) }\end{array}$ \\
\hline Sodium & AAS \\
\hline Potassium & AAS \\
\hline Calcium & AAS \\
\hline Zinc & \\
\hline
\end{tabular}

\section{Evaluation of the antibacterial activity}

Plant preparation and extraction. One (1) kilogram of the powdered leaves of $F$. odorata was soaked in $2.5 \mathrm{~L}$ ethanol (95\%) for 5 days with extract collection every after $24 \mathrm{~h}$. The collected leaf extracts was concentrated using a rotary evaporator (Eyela, USA) at $40^{\circ} \mathrm{C}$. The concentrated crude ethanolic leaf extract of $F$. odorata was stored in an amber bottle and was placed inside a refrigerator at $4^{\circ} \mathrm{C}$.

\section{Disc-diffusion method}

Preparation of bacterial inoculums and discs. Three Gram-positive and Gram-negative strains of bacteria maintained in Mueller Hinton (MH) agar were used in the study namely, Staphylococcus epidermidis, Bacillus cereus, Pseudomonas aeruginosa, and Klebsiella pneumoneae. A loopful of each strain of bacteria was inoculated on $\mathrm{MH}$ broth and was incubated for $24 \mathrm{~h}$ at $37^{\circ} \mathrm{C}$. Then, the turbidity of the bacterial suspension was adjusted to 0.5 McFarland standard, that is approximately equivalent to $1.5 \times 10^{8} \mathrm{CFU} / \mathrm{mL}$. This was used for the standardization of every antibacterial assay. 
Whatman filter paper No. 1 discs of $6 \mathrm{~mm}$ diameter were sterilized using hot air oven at $160^{\circ} \mathrm{C}$ for $1 \mathrm{~h}$. Then $20 \mu \mathrm{L}$ of the test extract containing $2 \mathrm{mg} / \mathrm{mL}$ was introduced on the sterile paper discs, and the solvents were allowed to evaporate on a stream of air. The solvents used for dissolving the extracts served as negative controls, while reference antibiotics cephalothin (C; $30 \mu \mathrm{g})$, vancomycin (V; $30 \mu \mathrm{g})$, amikacin $(\mathrm{A} ; 30 \mu \mathrm{g})$ and bacitracin (B; $10 \mathrm{U}$ ) were used as positive controls.

Antibacterial agar disc diffusion assay: KirbyBauer method. An aliquot of $0.5 \mathrm{~mL}$ bacterial suspension containing $1.5 \times 10^{8} \mathrm{CFU} / \mathrm{mL}$ was transferred on the surface of the MHA plates and was spread all over three times by rotating the plate $60^{\circ}$ after each streaking using a sterile cotton applicator. Subsequently, filter paper discs with the crude extract of $F$. odorata, negative control, and reference antibiotic discs were placed on the surface of the agar at equidistant points using sterile forceps. The plates were incubated at $37^{\circ} \mathrm{C}$ for $24 \mathrm{~h}$. Antibacterial activity was evaluated by measuring the diameter of the zone of inhibition to the nearest millimeter around the disc using a Vernier caliper. The tests were carried out in triplicate, and results were recorded as mean \pm SD.

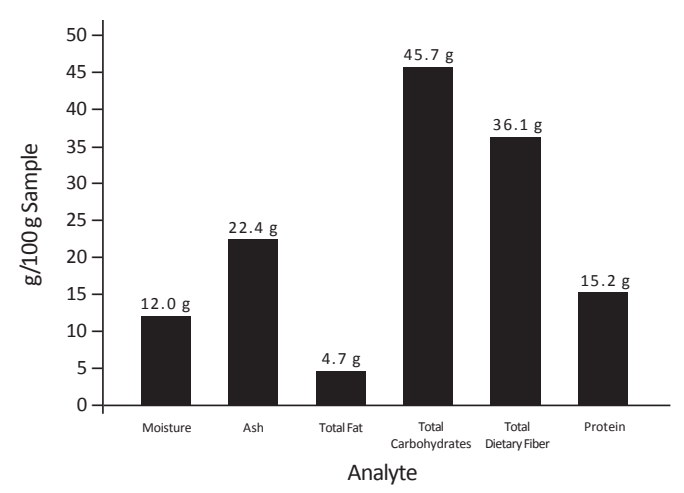

Figure 1. Proximate analysis of the major nutritional content of $F$. odorata.

\section{Results AND DISCUSSION}

Phytochemicals had contributed much to the recorded medicinal applications in every plant. Owing to a wide-range of benefits derived from indigenous plants, they become significant sources of dietary food supplements. Nowadays, consumption of fiber-rich plant sources is considered as the most leading functional dietary trends in the United States [6].

Figure 1 shows the total estimates for the major dietary components of $F$. odorata leaf. The plant contains $45.7 \%$ total carbohydrates and $36.1 \%$ total dietary fibers which the body may use readily as energy sources. Intake of dietary fibers (soluble and insoluble) lend several health benefits including risk-reduction for the development of coronary heart disease, stroke, hypertension, diabetes, obesity and gastrointestinal (GI) diseases [7]. In the Philippines, coronary heart disease $(13.73 \%)$ is the most prevalent cause of death followed by stroke (9.55\%) and hypertension (8.30\%) [8]. Their occurrence is usually related to the lifestyle practices such as dietary patterns, physical activity and cigarette abuse $[9,10]$. And that food consumption high in dietary fibers could reduce their prevalence $[6,7]$. A study had noted about $14 \%$ decrease in risk of all coronary events and $27 \%$ decrease in risk of

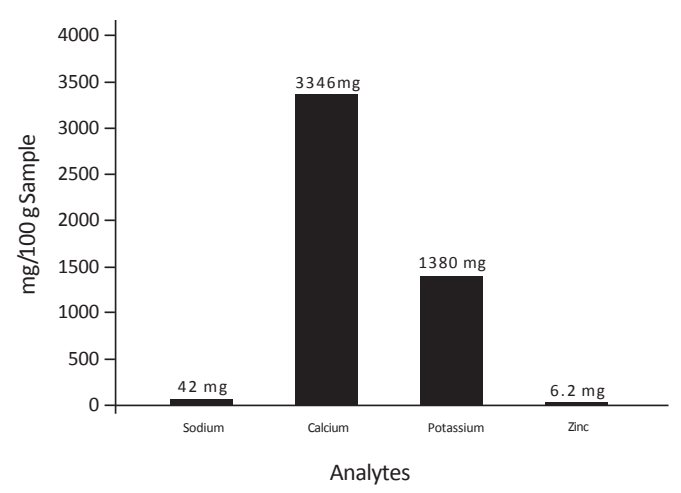

Figure 2. Proximate analysis of the micronutrients in F. odorata. 
coronary deaths during a 6-10-year follow-up investigation involving a $10 \mathrm{~g}$ /day increment of energy-adjusted [11] and measurement errorcorrected total dietary fiber consumption [7].

Moreover, inclusion of dietary fibers in the diet may also reduce the risk for diabetes mellitus. Fiber-rich foods are less energy-dense and larger in volume, which limits the spontaneous intake of energy and bring a feeling of satiety [12]. Furthermore, it is also considered to lower serum glucose level at 30-50 g fiber per day and fiber supplements at 10-29 g fibers per day may help in controlling sudden changes in the glycemic level [13]. These findings may also be related to the hypoglycemic activity of $F$. odorata towards streptozotocin-induced diabetes in SpragueDawley rats [2]. In this particular study, the DCM fraction of the plant (50 mg/kg and $200 \mathrm{mg} / \mathrm{kg}$ ) exhibited a significant decrease in the mean fasting blood sugar levels of diabetic rats after the 14-day treatment.

The plant contains also $15.2 \%$ total proteins. A diet containing wide variety of fiber-containing foods is also usually richer in micronutrients.
Figure 2 shows micronutrients are present in $F$. odorata leaf wherein calcium (3.35\%) is the highest followed by potassium $(1.38 \%)$ with trace amounts of sodium and zinc. These findings strongly suggest that its leaf is a highly nutritious food source for every undernourished and indigent Filipino.

Not only is F. odorata a good functional food ingredient in helping curb different lifestyle diseases but may find its way in the probiotic nutraceuticals inasmuch as it contains high amounts of carbohydrates, dietary fibers, proteins and micronutrients. As these molecules can serve as prebiotic food sources for probiotic bacteria (lactic acid and Bifidobacteria) they support synbiotic connection of gut microbiome. In diet, prebiotics are typically insoluble fiber compounds that enter the GI tract that induce the growth and/or activity of the gut microbiota.

To support the claim, antibacterial assay was performed on the freshly prepared $F$. odorata. Results showed no antibacterial activity against several standard ATCC strains such as Staphylococcus epidermidis, Bacillus cereus,
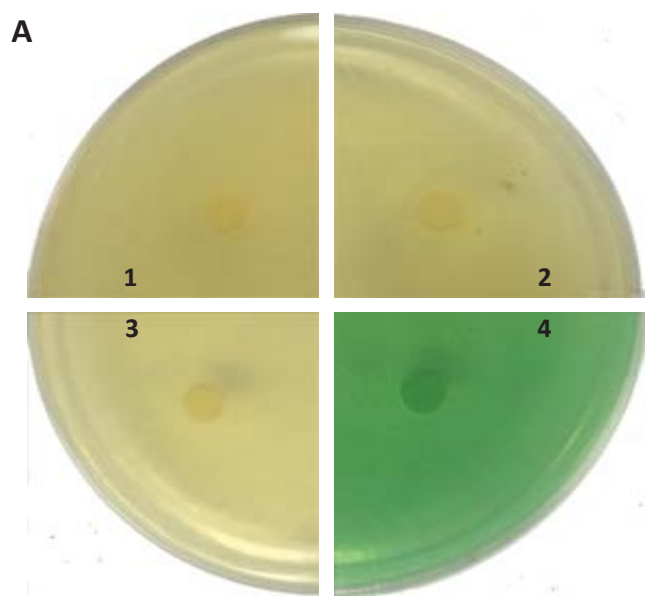

B
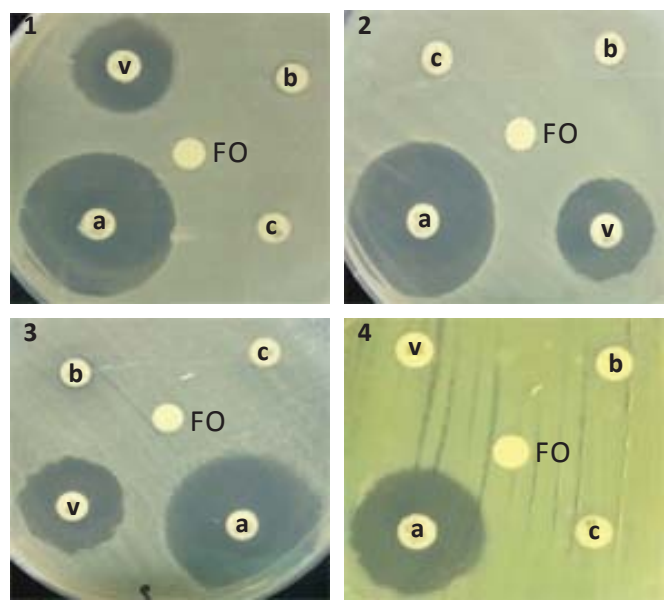

Figure 3. Disc diffusion assay. (A) No zone of inhibition was observed after a 24-h incubation of the crude ethanolic leaf extract of $F$. odorata with (1) B. cereus, (2) K. pneumoneae, (3) S. epidermidis, and (4) P. aeruginosa. (B) Zone of inhibition by standard antibiotics (a) Amikacin (b) Bacitracin (c) Cephalothin, and $(v)$ Vancomycin in contrast with the crude ethanolic leaf extract of $F$. odorata 
Pseudomonas aeruginosa, and Klebsiela. pneumoniae (Fig. 3). Results showed that F. odorata displayed no antibacterial activity with standard test microorganisms. However, most studies on other Ficus species on various parts of the plants extracted with different solvents including $F$. benghalensis, $F$. racemosa, F. auriculata, F. religiosa, F. glomerata, F. nitida, F. retusa, F. asperifolia, F. exasperate, F. carica, F. lyrata, F. deltoidea, F. palmate, and F. capensis revealed moderate to high antibacterial activity towards various strains [14].

Conversely, latest experiments demonstrated that the leaf extract of $F$. odorata can stimulate and sustain the growth of lactic acid bacteria in enrichment and cultivation MRS (de Man, Rogosa and Sharpe) agar and broth indicating that the extract has an important functional food ingredient that works as a prebiotic capable of supporting proliferation of probiotic bacteria [15] An elaborate work on this is in progress.

\section{CONCLUSION}

Ficus odorata Blanco is a potential functional food component with high dietary fiber, carbohydrates, proteins and mineral relevant in the formulation of probiotic nutraceuticals.

\section{ACKNOWLeDgment}

The authors thank the Philippine Council for Health Research and Development for the financial support of the study. Also, the authors would like to extend their gratitude to $\mathrm{Mr}$. Enrique Lorenzo Niño C. Panganiban for assisting in the antibacterial assays.

\section{REFERENCES}

[1] Herrera AA, Ramos JB, Ipulan LA. Teratogenic activity of Ficus odorata (Blanco) Merr.and Baccaureate tandra (Baill.) Müll in mice embryos. Phil Agri Sci. 2010; 93:255-262.
[2] Degollado JV, Yolo RT, Santiago LA. Hypoglycemic effect and in vitro antioxidant activity of the dichloromethane fraction from the leaves of Ficus odorata (Blanco) Merr. (Moraceae). Int. J. Res. Dev. Phar. Life Sci 2014; 3(5):1163-1173.

[3] Santiago LA, Mayor ABR. Prooxidant Effect of the Crude Ethanolic Leaf Extract of Ficus odorata (Blanco) Merr in vitro: Its Medical Significance. Int. J. Biol. Life Sci. Eng. 2014; 8(1):19-26.

[4] Santiago LA, Dayrit KC, Correa PCB, Aguila ACM, De Leon MRM, Mayor ABR. Cytotoxicity and genotoxic activities of the crude ethanolic leaf extract of Ficus odorata (Blco.) Merr. against human hepatocellular carcinoma. J. Pharmaco. Phytochem. 2014; 3(3):33-38.

[5] Tsai PW, De Castro-Cruz KA, Shen CC, Chiou CT, Ragasa CY. Chemical Constituents of Ficus odorata. Pharma. Chem. J. 2012; 46(4):225227.

[6] Slavin JL. Position of the American Dietetic Association: health implications of dietary fiber. J. Am. Diet. Assoc. 2008; 108(10):1716-1731.

[7] Anderson JW, Baird P, Davis RH, Ferreri S, Kundtson M, Koraym A, Waters V, Williams CL. Health Benefits of Dietary Fiber. Nutrition Reviews 2009; 67(4):188-205.

[8] World Health Organization. World Health Rankings, Philippines 2011. (http://www.world lifeexpectancy.com/country-health-profile/ philippines).

[9] Stampfer MJ, Hu FB, Manson JE, Rimm EB, Willett WC. Primary prevention of coronary heart disease in women through diet and lifestyle. New Engl. J. Med. 2000; 343:16-22.

[10] Kris-Etherton PM, Etherton TD, Carlson J, Gardner C. Recent discoveries in inclusive food-based approaches and dietary patterns for reduction in risk for cardiovascular disease. Curr. Opin. Lipidol. 2002; 13:397-407.

[11] Pereira MA, Jacobs Jr. DR, Pins JJ, et al. Effect of whole grains on insulin sensitivity in overweight hyperinsulinemic adults. Am. J. Clin. Nutr. 2002; 75:848-855.

[12] Giacco R, Rivellese AA, Lasorella G, Giacco A, Episcopo LD, Riccardi G. Long-term dietary treatment with increased amounts of fiver-rich low-glycemic index natural foods improves blood glucose control and reduces the number of hypoglycemic events in type 1 diabetic patients. Diabetes Care 2000; 23(10):1461-1466. 
[13] Jenkins DJ, Kendal CW, Vuksan V, Vidgen E, Parker T, Faulkner D, Mehling CC, Garsetti M, Testolin G, Cunnane SC, Ryan MA, Corey PN. Soluble fiber intake at a dose approved by the US Food and Drug Administration for a claim of health benefits: serum lipid risk factors for cardiovascular disease assessed in a randomized controlled crossover trial. Am. J. Clin. Nut. 2002; 75(5):834-839.

[14] Salem MZM, Salem AZM, Camacho LM, Ali HM. Antimicrobial activities and phytochemical composition of extracts of Ficus species: An overview. African J. Microbio. Res. 2013; 7(33):4207-4219.
[15] Panganiban ELC, Santiago LA. Development of Probiotic Nutraceuticals: Prebiotic effect of Ficus oodorata Blanco on the growth of Lactobacillus salivarius isolated from huan breast milk. Book of Abstracts of the $41^{\text {st }}$ Annual Convention of the Philippine Society of Biochemistry and Molecular Biology, p. 139. (Marco Polo Plaza Hotel, Cebu City; December 4-5, 2014). 